\title{
Modelling Freshwater Availability Using SWAT Model at a Catchment-Scale in Ivory Coast
}

\author{
Kouao Armand Anoh ${ }^{1 *}$, Tanoh Jean Jacques Koua ${ }^{1}$, Sampah Georges Eblin ${ }^{1}$, \\ Kan Jean Kouamé ${ }^{2}$, Jean Patrice Jourda ${ }^{2}$ \\ ${ }^{1}$ Environment Department, Jean Lorougnon Guede University, Daloa, Ivory Coast \\ ${ }^{2}$ Hydrogeology Department, Felix Houphouët-Boigny University of Abidjan, Abidjan, Ivory Coast \\ Email: ^anohkoua@gmail.com
}

How to cite this paper: Anoh, K.A., Koua, T.J.J., Eblin, S.G., Kouamé, K.J. and Jourda, J.P. (2017) Modelling Freshwater Availability Using SWAT Model at a Catchment-Scale in Ivory Coast. Journal of Geoscience and Environment Protection, 5, 70-83. https://doi.org/10.4236/gep.2017.513005

Received: November 16, 2017 Accepted: December 26, 2017 Published: December 29, 2017

Copyright $\odot 2017$ by authors and Scientific Research Publishing Inc. This work is licensed under the Creative Commons Attribution-NonCommercial International License (CC BY-NC 4.0). http://creativecommons.org/licenses/by-nc/4.0/

\begin{abstract}
Sustainable management of Ivory Coast's freshwater reserve at a catchment scale is an essential way in the policies of land use sustainable management. Thus, the implementation of physical conceptual semi-distributed SWAT model required a good knowledge of the watershed and a large number of physic-chemical data available that have been prior adapted to Ivory Coast's climatic and soil conditions. The whole simulation span was divided into calibration set (1982-1986) and validation set (1987-1990). The SUFI-2 algorithm was used for parameters optimization. The sensitivity analysis focused on 8 parameters related to runoff, soil, evaporation, main channel and groundwater. The performance criteria were based on the P-factor, R-factor and the two objective functions which are Nash-Sutcliffe coefficient and the coefficient of determination. Although Taabo river basin like African basins suffers from a significant lack of data, the objective functions showed the robustness of the model to climate variability. The calibration launched during a wet period gave objective functions higher than 0.7 while validation performed in less humid period gave performance criteria around 0.6. During the simulation period, Taabo river basin daily green water ranged from 0.044 to $50.257 \mathrm{~mm} /$ day with a total average of $3,090.9 \mathrm{~mm}$ per year. As for blue water, it is ranged from 0.032 to $0.552 \mathrm{~mm} /$ day with an annual total average of $29.19 \mathrm{~mm}$.
\end{abstract}

\section{Keywords}

SWAT, SUFI2, Taabo River Basin, Blue Water; Green Water

\section{Introduction}

Highly in great demand by all and sometimes at very large scale, freshwater or 
blue gold remains the natural resource without which, life on earth is not possible. Its scarcity, fragility and unequal distribution particularly on African continent has led to massive population displacement and in more serious situations, famine and death. Ivory Coast like other African countries is not sheltered from these spatial variability problems of water. Indeed, despite the heavy rainfall, the country faces problems of drinking water supply due to inadequate water resources, especially in dry season [1]. Besides, the problem of water availability is much more apparent in some regions compared to others. To remedy this, the Ivorian government launched in 1970, the National Fund for Water (FNH) to bring safe drinking water to populations who do not yet benefit. However, the lack of knowledge on water resources has hampered investigations. It is in this context that this study was conducted. The purpose of this study is to quantify the current state of Ivory Coast freshwater resources. It will allow from a relevant diagnosis of all physic-chemical phenomena, the assessment at the catchment scale of major water resources. An approach of this problem through tools such as hydrological models [2] [3] [4] [5] appears as a decision support tool to consider [6]. There are a variety of hydrological models, however, the spatial heterogeneity of the soil and the interactions complexity between climate, soil and plants does not enable predict with certainty the effects of different measures [7] [8] [9] [10] [11]. Thus, the SWAT (Soil and Water Assessment Tool) model, taking into account the spatial heterogeneity of the soil has been tested on the Taabo watershed. The choice of this model was also motivated by the inclusion in its database, of a wide range of cultures with different cultural practices [12] [13] [14]. Similarly, its ability to assess the water resources availability has been tested and validated on the African continent by [15]. The freshwater resources of the basin produced by SWAT model are divided into two components: blue water or internal renewable water resource (IRWR) and green water [16]. Blue water is the freshwater of aquifers, rivers and lakes that can be taken for various purposes including human consumption, irrigation, manufacturing, farming and hydropower. According to [17], it also supports aquatic ecosystems. It is quantified as the amount of water yield (which is the total amount of water leaving the subbasin and entering the main channel during a period time) plus the deep aquifer recharge (the amount of water from the root zone that recharges the deep aquifer during the time step) [11]. As for the green water, it is the precipitation part that naturally infiltrates into the ground and then returns to the atmosphere by transpiration from plants or evaporation from the soil surface. The water stored in the soil and productively used for plant transpiration is an important quantity particularly in rainfed agriculture [18]. [19] defined it as the sum of the green water storage (soil moisture (the amount of water in the soil profile at the end of a time period)) and the green water flow (actual evapotranspiration (the amount of water release to the atmosphere from soil evaporation and plant transpiration)). The model may contain errors, the evaluation of its performance was possible using the SUFI-2 (Sequential Uncertainty Fitting-Version 2) algorithm of SWAT-CUP software [20] and [21]. 
The SUFI-2 algorithm was chosen in this study because it proved its efficiency in the sensitivity/uncertainty analysis and calibration/validation of large watersheds demanding in terms of calculations. According to [16] and [22], it is capable of analyzing a large number of parameters and measured data from many gauging stations simultaneously. Thus, it is the most widely used algorithm in most hydrology studies because it requires a smallest number of model runs to obtain satisfactory results.

\section{Materials and Methods}

\subsection{Study Area}

Knowledge of the water availability problematic in the watershed requires knowledge of all phenomena and processes involved in its configuration. Thus, the Taabo watershed used as test zone in this paper is situated in Ivory Coast precisely between longitudes $4^{\circ} 59^{\prime}$ and $7^{\circ} 10^{\prime}$ east and latitude $6^{\circ} 07^{\prime}$ and $10^{\circ} 33^{\prime}$ north. It covers an area of $59,506.66 \mathrm{~km}^{2}$, in which $2975.33 \mathrm{Km}^{2}$ (either $0.05 \%$ ) is located in Mali (neighboring country). Taabo river basin benefits an important river system of which two artificial lakes that are Kossou and Taabo (Figure 1).

Indeed, created in 1971, Kossou Lake with a length of $150 \mathrm{~km}$ and an area of $1855 \mathrm{~km}^{2}$, is the largest lake in the basin. Its volume is estimated at full at $28.8 \times$ $10^{9} \mathrm{~m}^{3}$. As for Lake Taabo established in 1975, is located at $120 \mathrm{~km}$ downstream of Kossou Lake. Its lake covers an area of $69 \mathrm{~km}^{2}$ and stocks a volume of $630 \times$ $10^{6} \mathrm{~m}^{3}$ of water [23]. At the relief level, although having high altitude by location, Taabo watershed relief is mostly flat. The contributions transiting in the river basin come from tributaries of soil leaching, falling dead leaves and rejects of humans, animals and insects feces. The forte presence of human combined with its activities at the catchment surface has diverse repercussions both on water health, and socio-economical activities [24] [25] [26]. Among the water health consequences, one can non-exhaustively enumerate, sedimentation, acidification, pollution by heavy metals and eutrophication.

\subsection{SWAT Simulator Description}

SWAT model is the result of nearly 18 years of research initiated by the Agricultural Research Service of the Agricultural Department of the United States (United States Department of Agriculture (USDA) Agricultural Research Service) [27]. It is a semi-distributed, conceptual physical model that operates on a continuous basis with a daily time step. Some authors whom [28] and [29] considered it as an empirical model. This empirical consideration is because it includes some empiricism in particular in the representation of runoff (Curve Number method) or groundwater flow simplified from some empirical parameters such as the coefficient of drying up. Its license inducing-free use allows novice modeler to be support by the very large user community through its forums. SWAT offers also opportunities for changing and adjusting certain aspects of its source code for an adaptation to local conditions. It allows therefore managing heterogeneous watersheds 


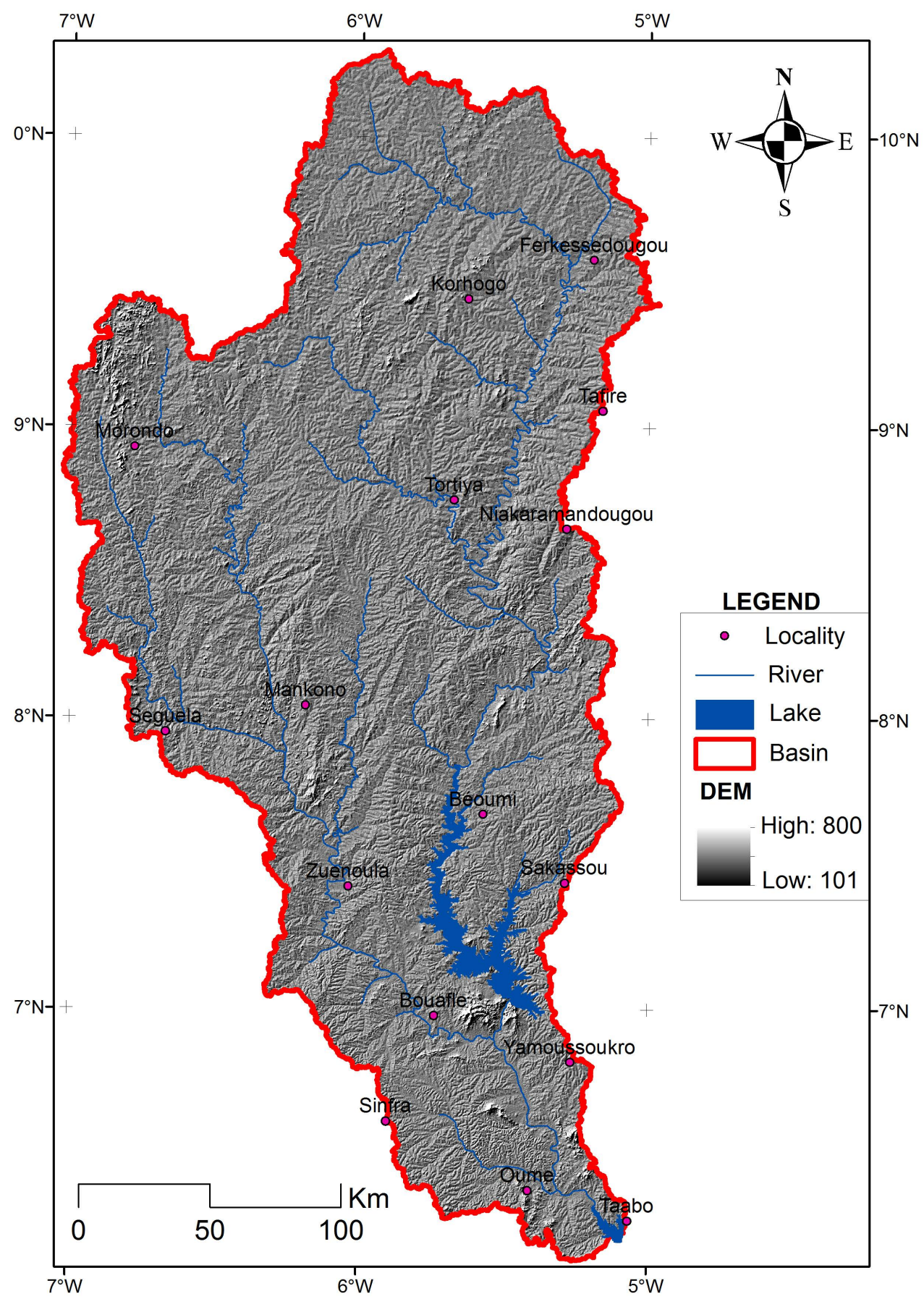

Figure 1. Study area.

in terms of landscape, land use, pedology and relief notwithstanding the size [14]. SWAT can also function in the absence of hydrometric data [30]. Thus, its coupling with GIS (Geographic Information System) as GRASS ${ }^{\circledR}$ or ArcGIS ${ }^{\circledR}$ is very useful as it promotes raster, vector and alphanumeric data management. This is a well-integrated agronomic and hydrological tool because its validity was tested on watersheds to various spatial-temporal scales and different agronomic and geological context. Among others, it has been tested in Morocco $\left(227 \mathrm{~km}^{2}\right)$ by 
[31]; France $\left(302 \mathrm{~km}^{2}\right)$ by [7] and $\left(385 \mathrm{~km}^{2}\right)$ by [8]; Quebec $\left(630 \mathrm{~km}^{2}\right)$ by [32]; Switzerland $\left(1700 \mathrm{~km}^{2}\right)$ by [33]; New Zealand $\left(2180 \mathrm{~km}^{2}\right)$ by [34]; United States $\left(4550 \mathrm{~km}^{2}\right)$ by [35]; Mali $\left(100,120 \mathrm{~km}^{2}\right)$ by [36] and [37]; Senegal watershed $\left(400,000 \mathrm{~km}^{2}\right)$, Volta watershed $\left(400,000 \mathrm{~km}^{2}\right)$, Niger watershed $\left(2.2\right.$ million $\left.\mathrm{km}^{2}\right)$ by [11] and throughout Africa by [15].

\subsection{SWAT Model Functioning}

In its setting up, SWAT subdivides the hydrological modeling of the basin into two phases [17]. In the first phase, which is the land phase of the hydrologic cycle, the model manages the amount of water, sediment loads, nutrients and pesticide flowing into the main channel of each subbasin. The second phase concerns the water transport, i.e. the movement of water, sediment, nutrients and other pollutants through the river network to the basin outlet. Depending on the number of HRU (Hydrologic Responses Unit), which is the basic unit of calculation, SWAT is able to reproduce in a few minutes or a few hours, several years of farming practices and hydrological functioning. Its hydrological structure reproduces water balance in a simplified manner through several interconnected modules via specific algorithms [38].

To simulate the availability of Taabo catchment water resources, the ArcSWAT 2009 related to ArcGIS 10.0 software was used. The ability of SWAT model to reflect the reality of the land is largely dependent on the accuracy and reliability of the input variables values of the model that will be incorporated. For its operation a database, which in most cases was freely obtained were used. Thus, Digital elevation model (DEM) used in this study was obtained by the mosaic of Shuttle Radar Topography Mission (SRTM) 35_10, 35_11 and 36_11 images at the resolution of $90 \mathrm{~m}$.

The land use map of Côte d'Ivoire of 2012 was obtained from the Center of Cartography and Remote Sensing (CCT (in French)) at a scale of 1/900,000. The soil map established by FAO in 1995 at a spatial resolution of $10 \mathrm{~km}$ taking into account 5000 soil types and physic-chemical properties of two soil layers whose depths range from $(0-30 \mathrm{~cm})$ and $(30$ to $100 \mathrm{~cm})$ [11]. Daily weather data of 56 stations ( 56 for precipitation and 56 for temperature) from the monthly weather statistics at a resolution of $0.5^{\circ}$ were obtained from monthly Climatic Research Unit (CRU) using the daily weather generator algorithm dGen. This work has been realized by [15]. There range from 1972 to 1990. Daily flow data from 1982 to 1990 were requested from the National Office of Drinking Water (ONEP in French). To reduce the duration of simulation, HRU (which is the result of the unique combination of land use, pedology and slope) was based on dominant texture and land use option. The Hargreaves and variable storage methods were respectively used to calculate evapotranspiration and hydrological flow. Surface runoff was simulated using a modification of the SCS Curve Number method (CN) [13]. The duration of the simulation which spread on 13 years was divided into three parts. The first period from 1978 to 1981 was used to warm up the model 
and the two other years (1982-1986 and 1987-1990), respectively used for the model calibration and validation. Model calibration determines the best, or at least a reasonable parameter set while validation ensures that the calibration parameter set performs reasonably well under an independent data set [39].

\subsection{SUFI-2 Algorithm}

The SUFI-2 algorithm (Sequential Uncertainty Fitting) of SWAT-CUP software [20] is a program which enables sensitivity analysis, uncertainty analysis, calibration and validation of SWAT model. SWAT model should undergo sensitivity analysis which consists of identifying most sensitive parameters to be tested in the model. The choice of these parameters was based in part on the literature (such as studies performed by [11] [15] [37] [40] [41] and on the other hand, the combination of Latin-hypercube and one-factor-at-a-time sampling strategy [42]. The uncertainty of input parameters in SUFI-2 is described as a uniform distribution, while model output uncertainty is quantified at the $95 \%$ prediction of uncertainty (95PPU) [43]. The 95PPU is calculated at the $2.5 \%$ and $97.5 \%$ levels of the cumulative distribution of an output variable obtained through Latin hypercube sampling, disallowing $5 \%$ of the very bad simulations [20]. The degree to which all uncertainties are accounted for is quantified by a measure referred to as the $\mathrm{P}$-factor, which is the percentage of measured data bracketed by the $95 \%$ prediction uncertainty (95PPU) [11] [44]. The goodness of calibration/validation and uncertainty prediction is judged on the basis of closeness of the P-factor to $100 \%$ and also by small uncertainty band depicted by R-factor. This R-factor which quantifies the strength of a calibration/uncertainty analysis is the average thickness of the 95PPU band divided by the standard deviation of the measured data. Similarly, to these criteria, the algorithm offers several objective functions. Among these multiple objective functions, the Nash-Sutcliffe coefficient (NS) and the coefficient of determination $\mathrm{R}^{2}$ were chosen because they provide a more accurate assessment of the model effectiveness in terms of the water flow and the absolute deviations [45]. The NS coefficient can vary from $-\infty$ (for a very poor fit) to 1 (which represents a strong link between the observed and simulated values). A NS below 0 indicates that the mean value of the variable should be the best prediction of the model result [15]. The $\mathrm{R}^{2}$ is ranged from 0 to 1 for a perfect model [39]. A value greater than 0.5 reflects a good concordance between observed and simulated data [46].

\section{Results and Discussion}

\subsection{Sensitivity Analysis}

SWAT generates a thousand input files and so there are a vast number of parameters to consider. Since all the sensitive parameters do not have the same impact on the model output variables, the Table 1 summarizes the SWAT model parameters range included in the final calibration/validation of Taabo river basin. On the 19 sensitive parameters listed in the bibliography for tropical humid 
Table 1. Initial and final ranges of SWAT model parameters used in calibration.

\begin{tabular}{cccc}
\hline Stream flow parameters & Definition & Initial range & Final range \\
\hline r_CN2.mgt & SCS runoff curve number for moisture condition II & $-0.60-0.20$ & $-0.37-0.11$ \\
r_SOL_AWC.sol & Available water capacity of the soil layer & $-0.20-0.60$ & $-0.33-0.29$ \\
v_ALPHA_BF.gw & Base flow alpha factor & $0.00-1.00$ & $0.17-0.73$ \\
v_GWQMN.gw & Threshold contribution of the shallow aquifer of channel flow & $100.00-3000.00$ & $944.77-2677.23$ \\
v_GW_DELAY.gw & Groundwater delay time (days) & $10.00-450.00$ & $221.91-651.69$ \\
v_CH_K2.rte & Effective hydraulic conductivity in the main channel & $15.00-250.00$ & $48.28-183.82$ \\
v_CH_N2.rte & Manning roughness for main channel & $0.00-0.30$ & $0.14-0.44$ \\
v_ESCO.hru & Soil evaporation compensation factor & $0.00-1.00$ & $0.02-0.68$ \\
\hline
\end{tabular}

With $\mathrm{v}_{-}$: parameter value is replaced by given value or absolute change; $\mathrm{r}$ : parameter value is multiplied by (1+a given value) or relative change [20].

Table 2. Taabo SWAT model statistical analysis.

\begin{tabular}{cccccccccc}
\hline \multirow{2}{*}{ Subbasin } & \multicolumn{3}{c}{ CALIBRATION } & \multicolumn{4}{c}{ VALIDATION } \\
\cline { 2 - 10 } & P-factor & R-factor & $\mathbf{R}^{2}$ & NS & P-factor & R-factor & $\mathbf{R}^{2}$ & NS \\
\hline 15 & 0.74 & 1.93 & 0.73 & 0.72 & 0.84 & 1.27 & 0.59 & 0.58 \\
30 & 0.89 & 1.72 & 0.85 & 0.84 & 0.90 & 1.28 & 0.57 & 0.55 \\
52 & 0.72 & 1.98 & 0.86 & 0.86 & 0.83 & 2.04 & 0.66 & 0.57 \\
\hline
\end{tabular}

area, only 8 parameters relative to runoff (CN2), soil (SOL_AWC), groundwater (ALPHA_BF, GWQMN and GW_DELAY), main channel (CH_K2 and CH_N2) and evapotranspiration (ESCO) are judged to be sensitive to Taabo sensitivity analysis.

\subsection{Calibration and Validation}

The results of statistical analysis give good values for coefficient of determination and Nash Sutcliff efficiency and performance criteria as well practically both for calibration and validation (Table 2).

Following stopping criteria of SUFI-2 model (P-factor and R-factor), the observation data are very good because in general, more than $80 \%$ are framed by the 95PPU. Besides, all the simulated meet the performance criteria established by [46] [39] [29] [47] and [48]. The Taabo SWAT model showed its robustness because for validation period, all stations have higher efficiency criteria than 0.5 . Similar values of the model were obtained by some authors [40] [41]. The great thickness of uncertainty strip is in part due to political crisis with corollary the lack of measurements steady. Also, among 82 subbasins discretized, only 11 precipitations and 5 temperature gages (on which some of them are outside of the river basin) are selected. In that situation, [47] suggests that the number of rainfall stations be equal to the number of subbasins for the model to be more accurate. Figure 2 shows the reproduction of Taabo river basin flow in which all the simulated river flow (Best_sim) matches well with the observed values. 


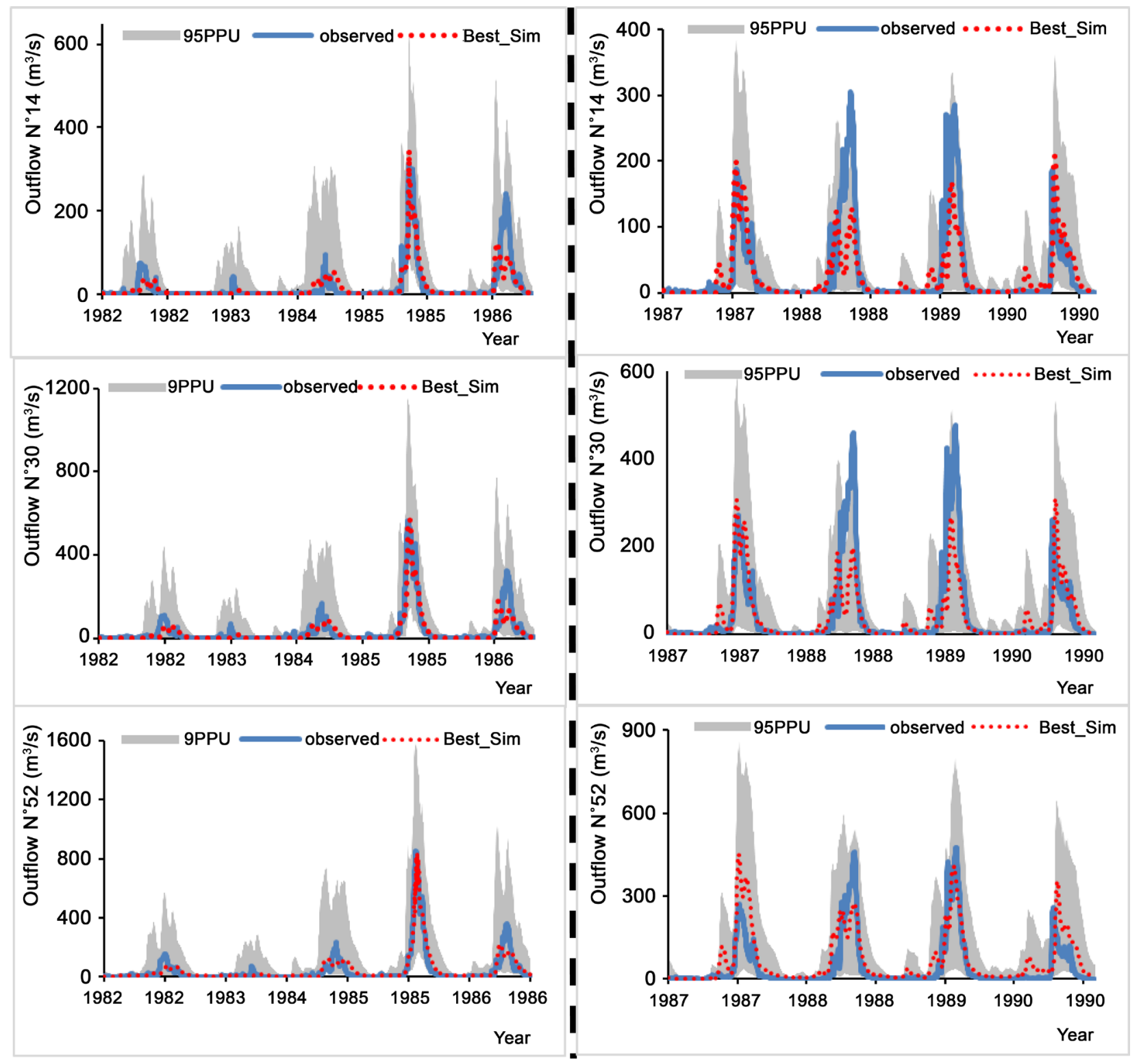

Figure 2. Measured and simulated daily outflow (left calibration period 1982-1986 and right validation period 1987-1990).

\subsection{Assessment of Water Reserves}

\subsubsection{Green Water}

During the simulation period (Figure 3), Taabo river basin daily green water is ranged from 0.044 to $50.257 \mathrm{~mm} /$ day with a total average of $3090.9 \mathrm{~mm}$ per year. The west part of the river basin (around Morondo and Seguela), upstream of Kossou lake (at Beoumi) and around Yamoussoukro, Oume and Sinfra localities are not favor for rainfed agriculture. It is for this reason the area in these parts are dominated by grass. Otherwise, because of the presence of gold mine reducing the presence of canopy between Kossou and Taabo lakes, the amount of water in the soil and to be evaporated is lower. The presence of lake (Kossou Lake) in the center part of Taabo river basin with high value of actual evapotranspiration increases the intensity of green water. 


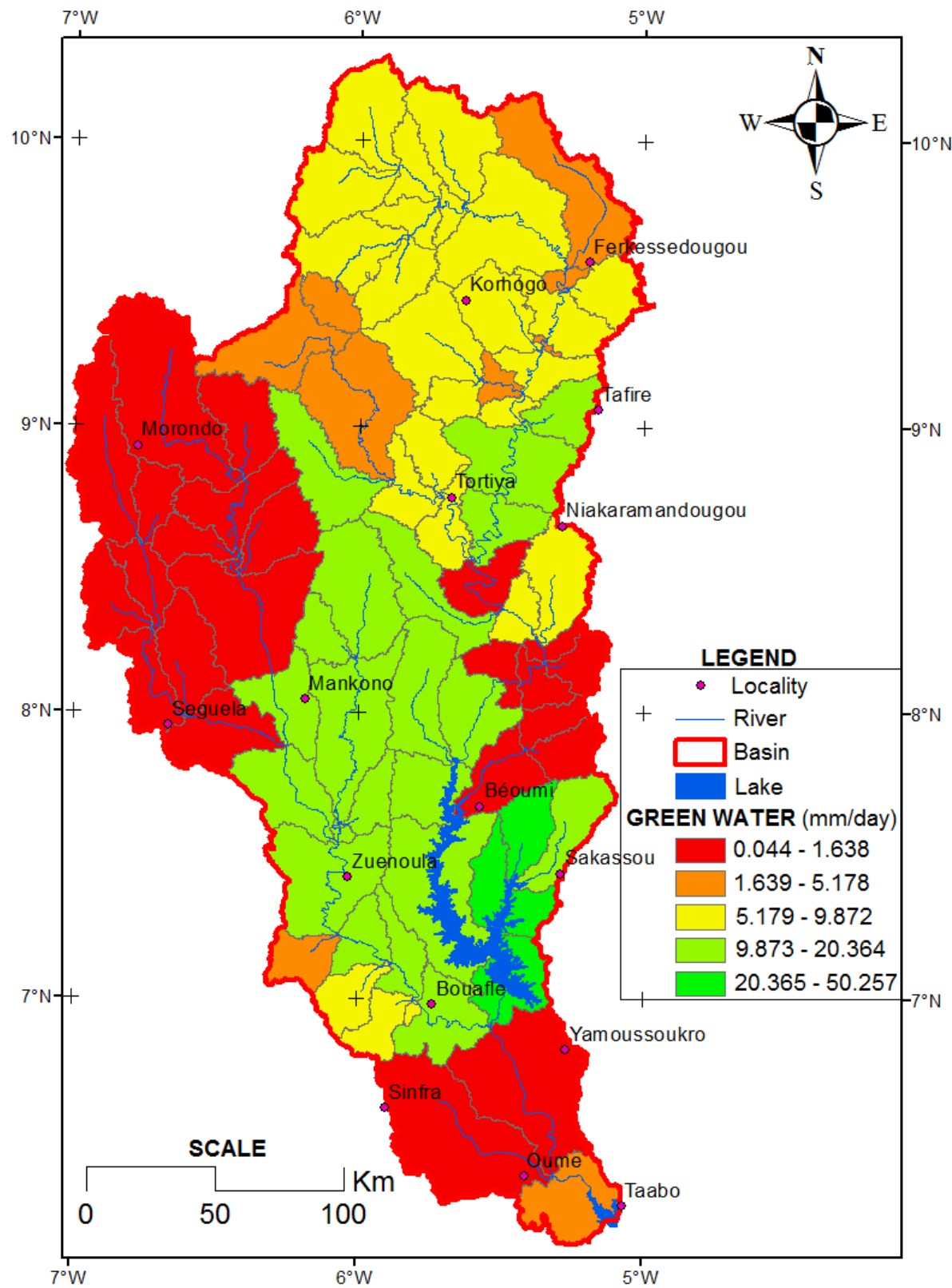

Figure 3. Evolution of different components of green water in Taabo catchment from 1982 to 1986 .

\subsubsection{Blue Water}

The flow and resources of Taabo blue water quantity and quality are closely determined by management practices of land users upstream. Indeed, as the catchment is much used for agriculture, the values of blue water are ranged from 0.032 to $0.552 \mathrm{~mm} /$ day (Figure 4). Outside surroundings Kossou Lake, all Taabo river subbasins contain less water ranging from 0.032 to $0.136 \mathrm{~mm} /$ day. The [49] which worked in Ivory Coast found that these areas are bit favorable for the implantation of manual drilling. The subbasin around Kossou Lake contains more blue water. The annual total average of blue water for the simulation period given by the model is $29.19 \mathrm{~mm}$. 


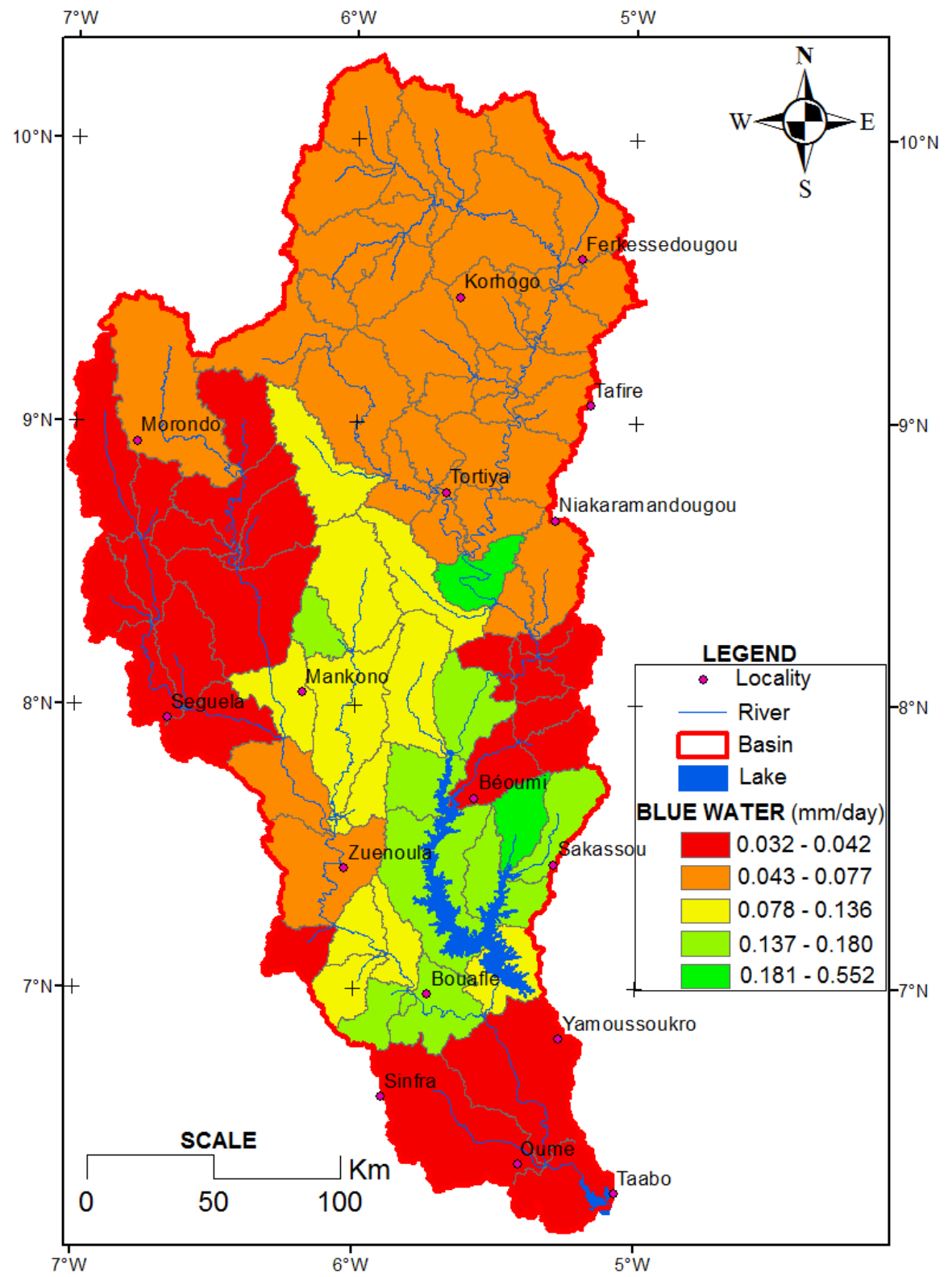

Figure 4. Evolution of different components of blue water in Taabo catchment from 1982 to 1986.

\section{Conclusion}

The study of Taabo river basin hydro-system consisted to determine the different freshwater resources from an agro-hydrological model. Despite its relative oldness, SWAT model remains little known in Côte d'Ivoire. So, this study is the first of its kind. The freshwater of Taabo river basin was simulated from 1978 to 1990 which split into three periods including warm up (1978-1981), calibration (1982-1986) and validation periods (1987-1990). The SUFI-2 algorithm was used for parameter optimization. Thus, 8 parameters were chosen for sensitivity analysis. Similarly, two criteria were used to stop iterations and two for the objective functions. The calibration period gave good results. However, because of the qual- 
ity of observation data, the model did not well represent the validation period. In the Taabo river basin, the green water is higher than the blue water. This study explains why the surface waters of the river basin are much used for drinking water of population near to the stream.

\section{Acknowledgements}

The authors wish to thank the Swiss Confederation that enabled the completion of this study through the granting a scholarship.

\section{References}

[1] Aké, G. (2010) Impacts de la variabilité climatique et des pressions anthropiques sur les ressources hydriques de la région de Bonoua (Sud-Est de la Côte d'Ivoire). $\mathrm{PhD}$ Thesis, Felix Houphouët-Boigny University of Abidjan, Abidjan.

[2] Andréassian, V. (2002) Impact de l'évolution du couvert forestier sur le comportement hydrologique des bassins versants. Paris, 6 .

[3] Ardoin-Bardin, S. (2004) Variabilité hydroclimatique et impacts sur les ressources en eau de grands bassins hydrographiques en zone soudano-sahélienne. Université Montpellier II-Sciences et Techniques du Languedoc.

[4] Varado, N. (2004) Contribution au developpement d'une modelisation hydrologique distribuee. Application au bassin versant de la donga, au benin. Doctor Thesis, Institut national polytechnique de Grenoble, France.

[5] Lay, M.L. and Galle, S. (2005) Variabilités interannuelle et intra-saisonnière des pluies aux échelles hydrologiques. La moussonOuest-africaineenclimatsoudanien. [Seasonal Cycle and Interannual Variability of Rainfall at Hydrological Scales. The West African Monsoon in a Sudanese Climate.] Hydrological Sciences Journal, 50, 509-524.

[6] Lévesque, É. (2007) Evaluation de la performance hydrologique du modèle SWAT pour de petits bassins versants agricoles du Québec. Master Thesis, Université Laval, Quebec City.

[7] Renaud, J. (2004) Mise en place du modèle agri-environnemental SWAT sur le bassin versant du Mercube (Haute-Savoie): Vers une modélisation des transferts de phosphore. [Rapport de Master SIG.] Université Jean Monnet, Saint-Etienne.

[8] Laurent, F., Ruelland, D. and Chapdelaine, M. (2007) Simulation de l'effet de changements de pratiques agricoles sur la qualité des eaux avec le modèle SWAT. Journal of Water Science, 20, 395-408. https://doi.org/10.7202/016913ar

[9] Rollo, N. (2007) Evaluation des risques de pollution diffuse al'echelle d'un sous bassin versant: Interet d'une approche par modelisation spatiale avec swat. L'exemple de la section amont du loc'h. Cnrs-Avignon, Université de Nantes, France, 8.

[10] Neitsch, S.L., Arnold, J.G., Kiniry, J.R., Srinivasan, R. and Williams, J.R. (2002) Soil and Water Assessment Tool User's Manual Version 2000. Grassland Soil and Water Research Laboratory Agricultural Research Service, 202, 472.

[11] Schuol, J., Abbaspour, K.C., Srinivasan, R. and Yang, H. (2008) Estimation of Freshwater Availability in the West African Sub-Continent Using the SWAT Hydrologic Model. Journal of Hydrology, 352, 30-49. https://doi.org/10.1016/j.jhydrol.2007.12.025

[12] Biesbrouck, B., Wyseure, G., Van Orschoven, J. and Feyen, J. (2002) AVSWAT 2000. KU Leuven, Leuven, 199. 
[13] Neitsch, S.L., Arnold, J.G., Kiniry, J.R. and Williams, J.R. (2011) Soil and Water Assessment Tool Theoretical Documentation Version 2009. Texas Water Resources Institute, College Station, 618.

[14] Arnold, J.G., Kiniry, J.R., Srinivasan, R., Williams, J.R., Haney, E.B. and Neitsch, S.L. (2013) SWAT 2012 Input/Output Documentation. Texas Water Resources Institute, College Station.

[15] Schuol, J., Abbaspour, K.C., Yang, H., Srinivasan, R. and Zehnder, A.J. (2008) Modeling Blue and Green Water Availability in Africa. Water Resources Research, 44, 1-18. https://doi.org/10.1029/2007WR006609

[16] Faramarzi, M., Abbaspour, K.C., Schulin, R. and Yang, H. (2009) Modelling Blue and Green Water Resources Availability in Iran. Hydrological Processes, 23, 486-501. https://doi.org/10.1002/hyp.7160

[17] Neitsch, S., Arnold, J., Kiniry, J., Williams, J. and King, K. (2005) Soil and Water Assessment Tool Theoretical Documentation. Grassland. Soil and Water Research Laboratory, Agricultural Research Service, Blackland Research Center, Texas Agricultural Experiment Station, 476.

[18] Gerten, D., Hoff, H., Bondeau, A., Lucht, W., Smith, P. and Zaehle, S. (2005) Contemporary "Green" Water Flows: Simulations with a Dynamic Global Vegetation and Water Balance Model. Physics and Chemistry of the Earth, Parts $A / B / C, 30$, 334-338. https://doi.org/10.1016/j.pce.2005.06.002

[19] Falkenmark, M. and Rockström, J. (2006) The New Blue and Green Water Paradigm: Breaking New Ground for Water Resources Planning and Management. Journal of Water Resources, 2006, 132.

[20] Abbaspour, K.C. (2007) User Manual for SWAT-CUP, SWAT Calibration and Uncertainty Analysis Programs. Swiss Federal Institute of Aquatic Science and Technology, Eawag, Duebendorf, Switzerland.

[21] Rouholahnejad, E., Abbaspour, K.C., Vejdani, M., Srinivasan, R., Schulin, R. and Lehmann, A. (2012) A Parallelization Framework for Calibration of Hydrological Models. Environmental Modelling \& Software, 31, 28-36. https://doi.org/10.1016/j.envsoft.2011.12.001

[22] Yang, J., Reichert, P., Abbaspour, K., Xia, J. and Yang, H. (2008) Comparing Uncertainty Analysis Techniques for a SWAT Application to the Chaohe Basin in China. Journal of Hydrology, 358, 1-23. https://doi.org/10.1016/j.jhydrol.2008.05.012

[23] Kaiser, E. and Constructors, I.-U. (1980) Aménagement hydroélectrique de Taabo. Rapport final de l'aménagement, 263.

[24] Bunea, F., Ciocan, G.D., Oprina, G., Băran, G. and Băbuțanu, C.A. (2010) Hydropower Impact on Water Quality. Environmental Engineering \& Management Journal, 9, 1459-1464.

[25] Török, Z., Ozunu, A. and Cordoş, E. (2011) Chemical Risk Analysis for Land-Use Planning. I. Storage and Handling of Flammable Materials. Environmental Engineering \& Management Journal, 10, 81-88.

[26] Weidema, B.P. and Lindeijer, E. (2001) Physical Impacts of Land Use in Product Life Cycle Assessment. Department of Manufacturing Engineering and Management, Technical University of Denmark, 1-52.

[27] Arnold, J.G. and Fohrer, N. (2005) SWAT2000: Current Capabilities and Research Opportunities in Applied Watershed Modelling. Hydrological Processes, 19, 563-572. https://doi.org/10.1002/hyp.5611 
[28] Lacroix, A., Laurent, F., Ruelland, D. and Sauboua, E. (2006) Nitrate Pollution Risk Assessment: From the Model to the Indicator. International Journal of Agricultural Resources, Governance and Ecology, 5, 206-223. https://doi.org/10.1504/IJARGE.2006.009164

[29] Gassman, P.W., Reyes, M.R., Green, C.H. and Arnold, J.G. (2007) The Soil and Water Assessment Tool: Historical Development, Applications, and Future Research Directions. Transactions of the ASABE, 50, 1211-1250. https://doi.org/10.13031/2013.23637

[30] Deslandes, J., Michaud, A. and Bonn, F. (2002) Développement et validation d'indicateurs agroenvironnementaux associés aux pertes diffuses de phosphore dans le bassin-versant de la rivière aux Brochets. Agrosol, 13, 111-123.

[31] Chaponniere, A. (2005) Fonctionnement Hydrologique d'un Bassin Versant Montagneux Semi-Aride: Cas du bassin versant du Rehraya (Haut Atlas Marocain). PhD, Institut National Agronomique, Paris.

[32] Beaudin, I., Deslandes, J., Michaud, A.R., Bonn, F. and Madramootoo, C.A. (2006) Variabilité spatio-temporelle des exportations de sédiments et de phosphore dans le bassin versant de la Rivière aux Brochets au sud-ouest du Québec. Agro-Solution, 17, 1-38.

[33] Abbaspour, K.C., Yang, J., Maximov, I., Siber, R., Bogner, K., Mieleitner, J., et al. (2007) Modelling Hydrology and Water Quality in the Pre-Alpine/Alpine Thur Watershed using SWAT. Journal of Hydrology, 333, 413-430. https://doi.org/10.1016/j.jhydrol.2006.09.014

[34] Cao, W., Bowden, W.B., Davie, T. and Fenemor, A. (2009) Modelling Impacts of Land Cover Change on Critical Water Resources in the Motueka River Catchment, New Zealand. Water Resources Management, 23, 137-151. https://doi.org/10.1007/s11269-008-9268-2

[35] Tong, S.T. and Naramngam, S. (2007) Modeling the Impacts of Farming Practices on Water Quality in the Little Miami River Basin. Environmental Management, 39, 853-866. https://doi.org/10.1007/s00267-006-0307-6

[36] Thiébault, M. (2010) Modélisation hydrologique d'un scénario de changement climatique sur le bassin versant du Bani avec SWAT [Mémoire d'ingénieur]: ENGEES, France.

[37] Laurent, F. and Ruelland, D. (2010) Modélisation à base physique de la variabilité hydroclimatique à l'échelle d'un grand bassin versant tropical. In: Servat, E., et al., Eds., Global Change: Facing Risks and Threats to Water Resources, International Association of Hydrological Sciences, 474-484.

[38] Rollo, N. (2012) Modélisation des dynamiques de pollution diffuse dans le bassin versant de la rivière d'Auray: quantification, caractérisation et gestion des apports nutritifs terrigènes. Thèse de Doctorat, Université de Nantes.

[39] Tolson, B.A. and Shoemaker, C.A. (2004) Watershed Modeling of the Cannonsville Basin using SWAT2000: Model Development, Calibration and Validation for the Prediction of Flow, Sediment and Phosphorus Transport to the Cannonsville Reservoir. Cornell Library Technical Reports and Papers, 159.

[40] Anoh, K.A. (2014) Apport d'un SIG et du modèle agro-hydrologique SWAT dans la gestion durable des ressources en eau du bassin versant du lac de Taabo (Centre de la Côte d'Ivoire). PhD, Félix Houphouët Boigny, Côte d'Ivoire.

[41] Anoh, K.A., Koua, T.J.J., Kouamé, K.J., Jourda, J.P. and Laurent, F. (2017) Modelling Water Flow in a Complex Watershed in Humid a Tropical Area using Swat: A Case Study of Taabo Watershed in Ivory Coast. International Journal of River Basin 
Management, 1-11.

[42] Van Griensven, A. and Meixner, T. (2006) Methods to Quantify and Identify the Sources of Uncertainty for River Basin Water Quality Models. Water Science and Technology, 53, 51-59. https://doi.org/10.2166/wst.2006.007

[43] Hosseini, M., Amin, M., Ghafouri, A. and Tabatabaei, M. (2011) Application of Soil and Water Assessment Tools Model for Runoff Estimation. American Journal of Applied Sciences, 8, 486-494. https://doi.org/10.3844/ajassp.2011.486.494

[44] Singh, V., Bankar, N., Salunkhe, S.S., Bera, A.K. and Sharma, J. (2013) Hydrological Stream Flow Modelling on Tungabhadra Catchment: Parameterization and Uncertainty Analysis using SWAT CUP. Current Science, 104, 1187-1199.

[45] Bioteau, T., Bordenave, P., Laurent, F. and Ruelland, D. (2002) Evaluation des risques de pollution agricole à l'échelle de bassins versants: Intérêts d'une approche par modélisation hydrologique avec SWAT. Ingénieries-EAT, 32, 3-13.

[46] Santhi, C., Arnold, J.G., Williams, J.R., Dugas, W.A., Srinivasan, R. and Hauck, L.M. (2001) Validation of the Swat Model on a Large Rwer Basin with Point and Nonpoint Sources. JAWRA Journal of the American Water Resources Association, 37, 1169-1188. https://doi.org/10.1111/j.1752-1688.2001.tb03630.x

[47] Obuobie, E. (2008) Estimation of Groundwater Recharge in the Context of Future Climate Change in the White Volta River Basin. Ecology Series, 153.

[48] Abbaspour, K. (2013) User Manual for SWAT-CUP: SWAT Calibration and Uncertainty Analysis Programs. Eawag: Swiss Federal Institute of Aquatic Science and Technology, Duebendorf, 103.

[49] Unicef (2007) Etude de faisabilité des forages manuels identification des zones potentiellment favorables. République de Côte d'Ivoire, 73. 